\title{
滑動性追従眼球運動の定量的評価法
}

\author{
名古座市立大学医学部耳咽喉科学政室（主任：馬埸酸吉教授） \\ 羽柴之, 安井桂子、渡部壁素 \\ 松岡徹, 馬埸睃吉
}

\section{QUANTITATIVE ANALYSIS OF SMOOTH PURSUIT EYE MOVEMENT}

\author{
MOTOYUKI HASHIBA, M.D., KEIKO YASUI, M.D., HIROTAKA WATABE, M.D. \\ TORU MATSUOKA, M.D. and SHUNKICHI BABA, M.D. \\ Department of Otorhinolaryngology, Nagoya City University Medical School, Nagoya
}

\begin{abstract}
Abnormalities of smooth pursuit eye movement (SPEM) have been estimated, mainly using the wave form on an electro-oculogram. in a qualitative way. Many methods for quantitative analysis of SPEM have been designed, though most are still uncommon in present clinical use. Using a personal computer. we developed a method of automatic quantitative analysis of ocular tracking eye movement recorded by electro-oculography (EOG). The design concept of this method is based on the observation that eye movement during ocular tracking consists of two different kinds of eye movements, one is SPEM and the other is saccade. The combination of SPEM and saccade (composite eye movement : CEM) commonly appears during ocular tracking. These two kinds of eye movement are essentially different not only in behavior but also about involved neural pathway in the central nervous system. From this point of view, we believe that the two kinds of eye movements involved in ocular tracking should be evaluated separately.

The analysis method is outlined as follows. A horizontal sinusoidally moving visual target was employed to elicit ocular tracking eye movements. The test frequencies were set at $0.1,0.2$, 0.4 and $0.8 \mathrm{~Hz}$, and the amplitude of target motion was $15 \mathrm{deg}$ at each frequency. The 20 seconds of eye movement data measured by EOG were fed into the computer through a digital-analog converter for further analysis. Using our original saccade detection algorithm, based on the physiological behavior of saccades, the saccadic components were detected and removed from the eye movement wave. The remaining parts, fragments of SPEM, were connected by means of interpolating defective parts. The reconstructed wave was a slow cumulative eye position curve (SCEP). Sinusoidal target motion, CEM and SCEP were processed by the FFT (Fast Fourier Transformation) method. Bode plots were applied to summarize the gain and phase of responses to SCEP and the target motion wave.

These processes enable us to estimate abnormalities of SPEM such as low gain, abnormal phase shift and large trends in tested duration. We conclude that the method described here is useful for quantitative estimation of SPEM in clinical neuro-otological examinations.
\end{abstract}

Key words：滑县性追従眼球運動，定贯評価，コンピューター

A $98-0681-10522$

はじに

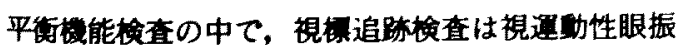

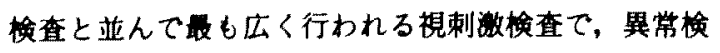
出率も高く重要な位俨を占めてきた。視標追跡娭査の 
手法は，单なる肉眼的覞察から電気眼振計 (Electronystagmography：ENGあるいは Electro-oculography : EOG 以下EOG と略す)を使用するものまでさ まざまてあるが，その評価については䀧者の主覞に頼

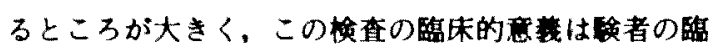
床経駼に大きく左右された。このような久点を克服す ヘく，従来よりいくつかの定基詊価の方法が提唱され てきだ!2!.特に近年バーソナルコンビューターの普及 に伴い波形分析が比较的容易に行い㑩る状況となり， コンピューターを用いた分析方法が多数発表されてき

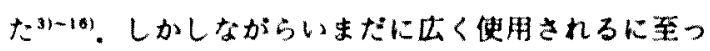
ていない.

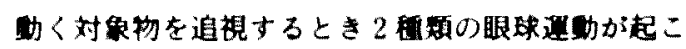

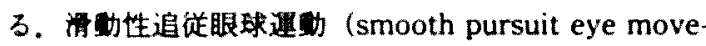

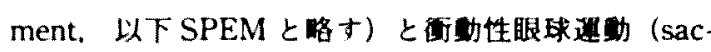
cadic eye movement, 以下 saccade と記す)てある。

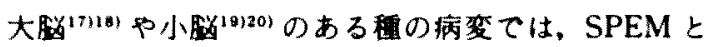
saccade が別々に潭害されること，また両者はそれも 几異なった潜時を持ち21122)，以下に述へるように様々

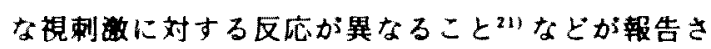
几、両者はその神経路，制御システムが全く別のもの ておることかかかっている。

SPEM は比较的ゆっくり钐く対象物を中心窝で捕

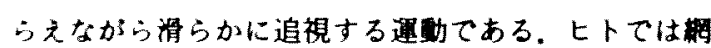
㬴上での像の移動速度が $2.5 \%$ sec 以上になると視力 の維持がでなくなることがわかっており 231241，良好 な覞力を保つためには，視对象物の移㽖速度と眼球の 追跡速度を伍力一致させることが必要てある，従来こ

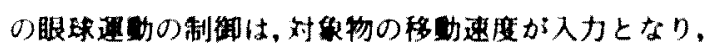

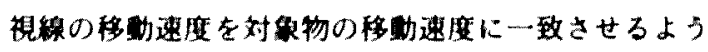
な negative feedback 制御によりなされていると考え られてきだ21.したがってこの眼球遇助には通常消ら

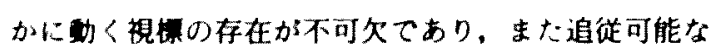
視埧速度も30\% $\mathrm{sec}^{221}$ 加的 $45^{\circ} / \mathrm{sec}^{23)}$ 程度の遅いスピ ードに限られるとされてきた。しかしながら，その後 の研究によりある特殊な条件下では，この眼球運動を 引き起こすために，実际に消らかに䡃く視栖を必要と

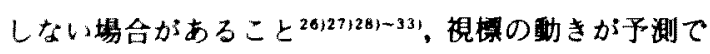
きにくい時には，迤い視彞速度ても滑らかに追視する ことができいこど4ー37!などが明らかになり，空間 における遇動知賞や予湖制御などの，より高次の神経 活㽖か関与していることが明らかになりつつある。そ 几と共に，制御铪的立埸からも单純な negative feed. back 制御では説明てきないことが理解され、さまさま
な新しい制御系モデルが提案されている38139140).

一方 saccade は視標と視線の位㯰のスレの大きさ が入力となり，眼球の移野量が決められる，この眼球 の移娌吾は saccade が開始される前にすてに決定さ れ, saccade 開始直前に目標となる視標を移動させて も，その視栖が存在した場所に眼球が動くことが知ら れている゙!.これらの制御機檋の異なる二つの眼球運 助のコンビネーションにより，動く梘莧対象物を効率 よく中心需て捕らえることがてきる。すなわち，対象 物の速度が遇いときはSPEMて視標を捕らえ，また 視樏速度が速くなりSPEMて迫えなくなったり，梘

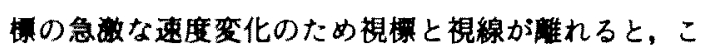
れを補正するたかに saccade が出現する.そして中心 需に梘賞対象物を捕らえると再びSPEM系が㑬き梘 彁を追跡する。

このようにして全く独立した 2 㮴類の眼球運動から 成り立っている視標追跡遣娌を平価するためには，ま ず SPEM と saccade を区別して伻価することが合理 的でる。.このような镜点から，我々はコンピュータ 一を利用して saccade と SPEM を自動的に分離し評 価する方法を武みた。またシステム評価のためには周 波数応答法を用いた。これは，自動制御理論の重要な 一手法てあり，分析しょらとする系に正弦波入力を加 えたときに，出力として出てくる正弦波を取り出し， 入出力間を比する。すすなら両波形間の振幅比, 位 相琴を計算し, 正弦波入力の周波数を変えると各周波 数においてこれらがどのように变化するかということ てその系の特性を嗦析しようとする方法てある。

本詥文ては我々の開発したアルコリスムの概要につ いて述へ，現在まてに発表されてきた定典解析の方法 と比䑤するとともに、コンピューターを用いた自動定 奥解析における諸問通について考察する。

\section{研究対象お上U゙方法}

1. 研究対象

被者は正常者 8 名抢よび肉眼的涀察により SPEM に等を㑇めためまい患者である。

2. 跤期

1) 刺激装目

視刺敞装置は明所下で被敇者の前方 $1 \mathrm{~m} の$ Jung 型

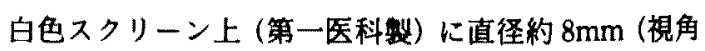
約 $0.5^{\circ}$ )の赤色レーザースポットにより視標を投影(第 一医科慗した。これを、パーソナルコンピューター (NEC PC-98XL2) から発僧し D-A 变換器（マイクロ 


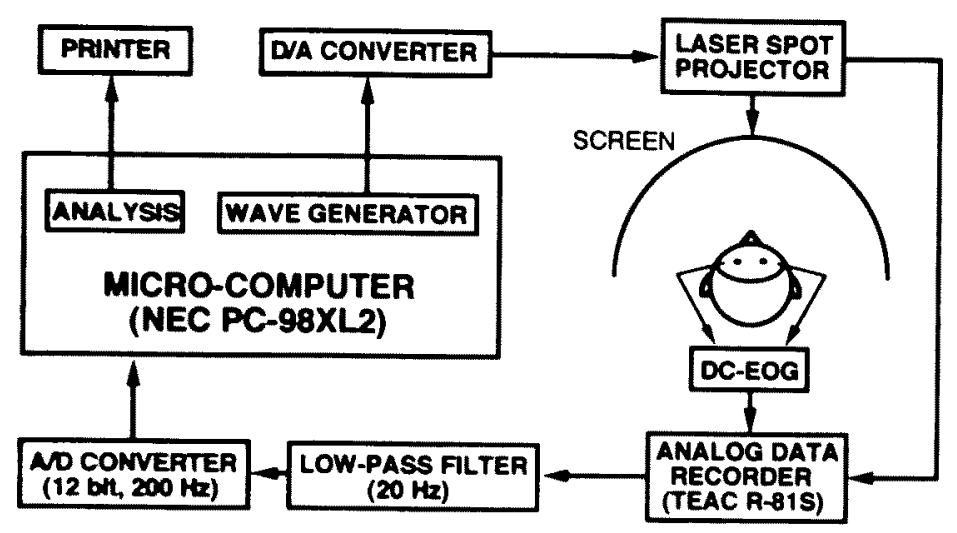

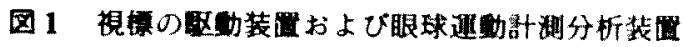

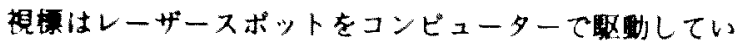
ろ. 視相の娌さE EOGはいっだんデータレコーターに 記椂され，その後コンピューターで分析される。

サイエンス社 TDA-2498BPC) を通してアナログ化 した出力て，措幅左右 $15^{\circ}$ ザつ $0.1 \mathrm{~Hz}, 0.2 \mathrm{~Hz}, 0.4 \mathrm{~Hz}$,

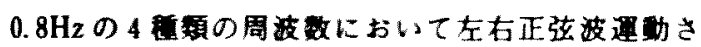

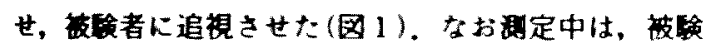

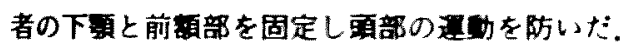

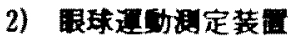

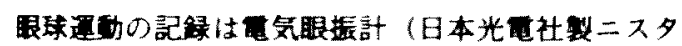
クモグラフ用アンプ AN゙-601G)に上りDC-EOG で両

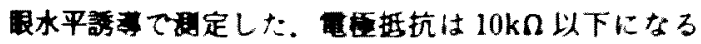
ようにした，EOGの校正は各被頓者ことに左右 $15 \% の$ 梘㧤を交互注視することにより行った。

3）分析䒾置

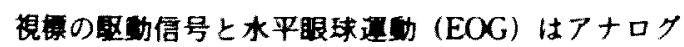
テータレコータ（TEAC 新 R-81S）に記録した。デ ータレコータ加ら再生した信号は $20 \mathrm{~Hz} の$ low pass

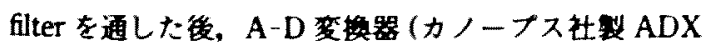

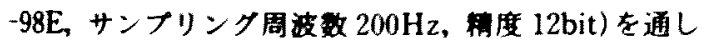
てテシタル信号に変揬し、パーソナルコンピューター により颀理しだ. 莭果はプリンターに出力されかつ磁 気ディスク保存した(图1)。1回のテストデータ30 移の内20.48sec (4096点) のデータを処理した。

3. 解析のアルゴリスム

解折に用いたアルコリスムは，以下に示すような

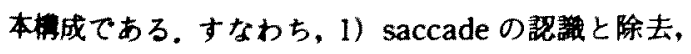
2)除去された saccade 区間の補完によるSPEM の 再棈築 (これを slow cumulative eye position, 以下 SCEP と略す $\left.{ }^{42)}\right)$ ，3）SPEM と saccade から满成され
万眼球運動の原波形 (composite eye movement, 以 下CEMと略す)，再棈築した SPEM (SCEP) 各々の 周波数分析の三つから構成されている。をの流れを図 2 に示す。

1) saccade 認識のためのアルコリスム

図2のAからBの間の saccadeの訆識方法を図 3 に示す。まず，速度波形で折り返しているピークの部 分を楑し，この部分が saccade として妥当であるか必 要十分ないくつかの条件を以下に述へるように設定し た。れそれの条件は一般的に啒められている saccade の特性に基ついている゙か34445).

(a) $|\mathrm{Vi}|>|\mathrm{Vth}(\mathrm{t})|$

saccadeの速度は常に視情の昉きおよびその時の SPEMの速度より速いはずでる。生た saccadeの潜 時仙約 150-200msec といわれている.そこで, 検出さ れた速度波形のピーク部分 (saccade)より $150 \mathrm{msec}$ 前 の入力波（視摽の動き）の速度を計算し，これを1.2倍 した值を速度閜值 $(\mathrm{Vth}(\mathrm{t}))$ とし, saccade の速度 $(\mathrm{Vi})$ がこの速度阴値よりも大きいこをを条件とした， 1.2 倍という数檤はデータに混入しているノイスと被験者 ことに翼なる位相のスレを考虑したものであり，我々 の経段に基づいた数值であるが，さらに最適な值を検 討する余地がありプロクラム上可変にしてある。 また 視整速度が非常に小さい場合を考虑して速度閵值の曼 低值を $20 \%$ sec に設定した。

(b) $x(E)-x(S)>$ Ampth saccadeの始点（S）と終点（E）を決定し, saccade 


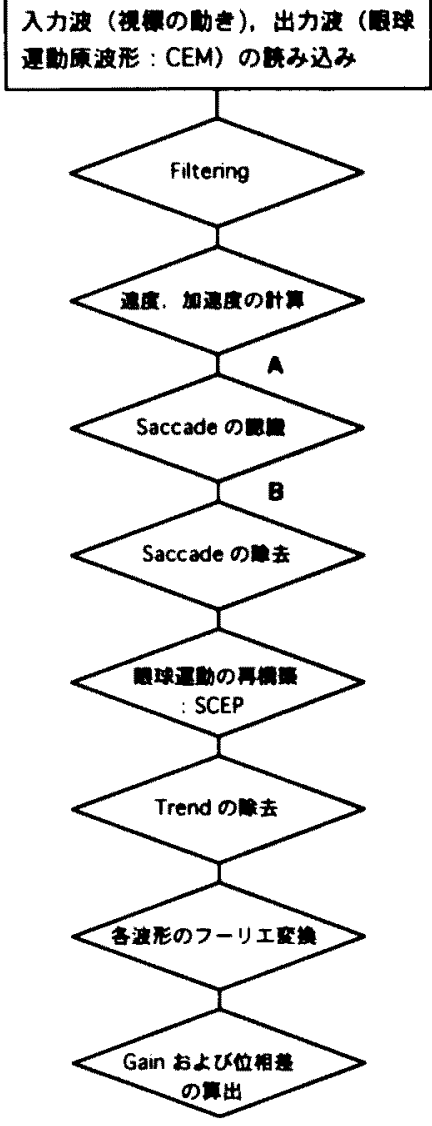

图 2 分析のアルコリスム 分析のアルコリスムの基本成を示す。

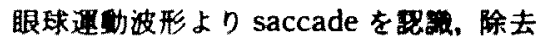
し, SPEM 成分のみをつなき合わせて波 形を再的築する。再碃築した波形 (slow cumulative eye position: SCEP) に対 して周波数分析を行引。

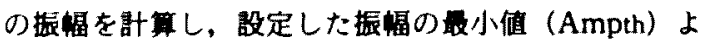
りも大きいかをチェックした，振幅の最小值は，どの くらい小さな saccadeまで検出てきるかということ を意味し，ノイス成分の大きさによって決まる．EOG の場合ノイスの少ない場合ても模出可能な saccade

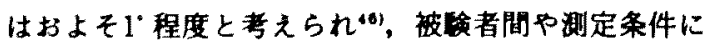
よってもノイスの大きさは異なってくろので, 今回振

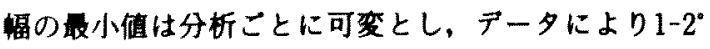
の筑用て設定を変更した。

(c) $50 \mathrm{msec}<\mathrm{E}-\mathrm{S}<200 \mathrm{msec}$ saccade の持繶時間は 50-200msecに股定した。す
なわち, $50 \mathrm{msec} よ り$ 短いものはノイス, $200 \mathrm{msec}$ を㗉 えるものは, SPEM と判断した。

(d) $\left|\mathrm{a}\left(\mathrm{T}_{1}\right)\right|>$ Accth and $|\mathrm{a}(\mathrm{T} 2)|>$ Accth

saccade の立ち上がりおよび次の pursuit への移行 が急峻でるかを調へる項目て，加速度の絶対值の最 大值 $\left(|\mathrm{a}(\mathrm{T} 1)| ，\left|\mathrm{a}\left(\mathrm{T}_{2}\right)\right|\right)$ を求め，設定した加速度睹 值 (Accth)より大きいことを条件とした，加速度的值 も分析ごとに可変としたが，今回はおよそ200-500\% $\sec ^{2}$ て設定すると，良好に saccade を模出てきた。

(e) $\mathrm{V} \geqq \mathrm{pA}+\mathrm{q}$

saccadeの振幅と樶大速度は指数阙数の関係にあ ろ がが,比校的小振幅の部分に限れば比例蔺保に近似 し得ろ‘3).すなわち，小さな saccade は速度が皘く， saccade の振愊が大きくなるとその速度も速くなる. 实㮏のデー夕から用手的に抽出したいくつかの saccadeからこの近似的比洌閔係の下限を求めた。分析

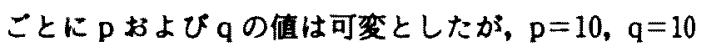
て設定した㥂合が佰頼性が高かった。

以上のすべての条件を满だしたものを saccade と して訆させ、こ こaccade 部分を取り除き，その区 間を前後 $20 \mathrm{msec}$ 成の速度の平均值を用いて補完し, つなき合わせ，SPEM 成分のみで波形を再楼築した (SCEP).

\section{2) 周波数分析}

今回の分析方法ては, saccade そのものに対する分 析は行っていない. しかし, saccade の gainの異常 (saccadic dysmetria) は CEM の gainの異常といち 形でわれる.

SCEP は，周波数分析の前に最小二乗法によりトレ ンド（解析時間内の波全体の傾き）を除去した。 これ はトレンドが低周波数成分の解析結果に影するのを さけるためてある.SPEMのgainに右向きと左向き て差がある㘿合は、トレンド值の增大という形て表さ れる.

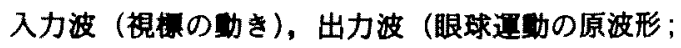
CEM)，再筑した SPEM (SCEP)の各々を高速フー リ工変 (Fast Fourier Transformation: FFT) L, パワースベクトルを求め, 入力波の周波数成分に拈け る利得（gain）まよび位相差（phase）を計算した。

\section{1. 正常例}

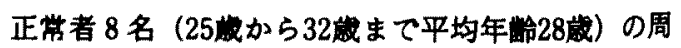


(a)

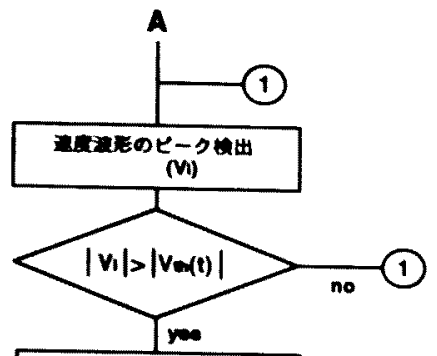

(b)

(c)

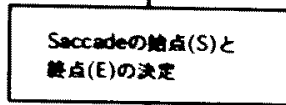

(d)

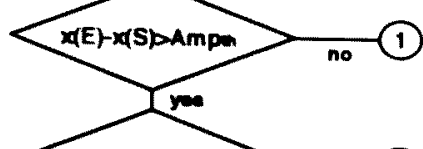

(e)

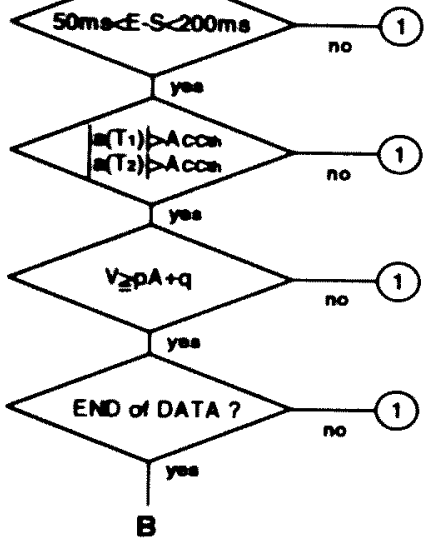

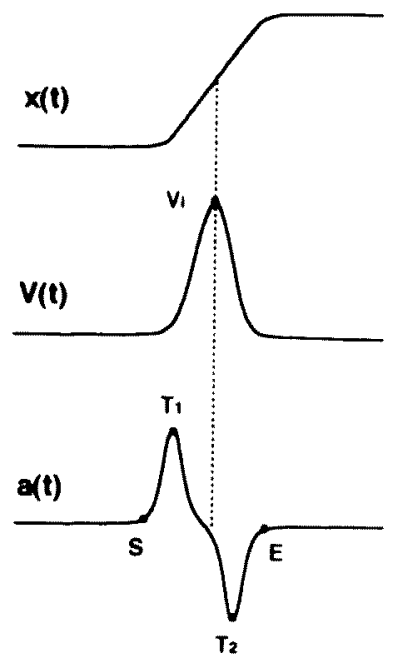

因 3 saccade 陻憫のためのアルコリスム

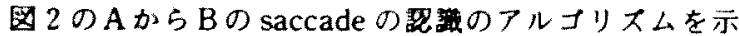
す. (a) $\mathrm{Vi}$ : saccade $の$ 速度, $V$ th $(\mathrm{t})$ : 速度值 $(150 \mathrm{msec}$ 前の視标の速度を1.2倍した储)，(b) S : saccade の始点, $E$ ： saccade $の$ 終点, $x(E)-x(S)$ : saccade $の$ 振棏, Ampth : 設定した saccade の持続時間, (d) $\left|a\left(T_{1}\right)\right|$ : sac. cadeの始点の加速度の絶対值，|a(T2)|: saccade の点の加束度の最大絶対值，Accth：設定した加速度域 值, (e): v: saccade $の$ 速度, A : saccade $の$ 振幅，p，q： 定数。右㑡の波形は， $X(\mathrm{t})$ : 眼球連䖝波形, $V(\mathrm{t})$ : 眼球

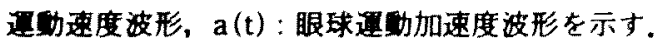

波数分析の結果如よ゙トレンドを表1に示す。これを グラフ化したものが图 4 て，入力波の周波数の変化に 伴う gain および phase の変化を示す Bode 線园であ ろ. $0.8 \mathrm{~Hz}$ でのみ SCEPにおける gainの低下，すな かち SPEM の gain の低下がかずかに㲅められる. 一 方 CEM では $0.8 \mathrm{~Hz}$ においても gainの低下はなく， SPEM と saccade のコンビネーションにより正確な 追従がでていることを示している，phase は CEM， SCEP ともにわずかな位相痋れがみられ，周波数の増 加と共に增大する傾向がみられる。トレンドは SPEM の左右差をみる指楔て，正常者では值は小さく，速度 の左右差はほとんど蹃められなかった。

2. 翼常例

1) gain の異常例 
表 1 正常者の周波数分析とトレンド

\begin{tabular}{|cc|c|c|c|c|c|c|}
\hline & & \multicolumn{2}{|c|}{ Gain } & \multicolumn{2}{c|}{ Phase (deg) } & \multicolumn{2}{c|}{ Trend (deg/sec) } \\
\hline \multirow{2}{*}{ CEN } & & Means & S.D. & Means & S.D. & Means & S.D. \\
& 0.1 & 0.969 & 0.05 & 2.92 & 2.66 & & \\
& 0.2 & 0.944 & 0.048 & 4.76 & 0.58 & & \\
& 0.4 & 0.941 & 0.059 & 10 & 0.82 & & \\
& 0.8 & 0.894 & 0.077 & 22.04 & 1.26 & & \\
\hline SCEP & 0.1 & 0.832 & 0.074 & 2.48 & 2.18 & 0.209 & 0.13 \\
& 0.2 & 0.901 & 0.05 & 5.08 & 1.08 & 0.115 & 0.061 \\
& 0.4 & 0.858 & 0.049 & 10.75 & 1.35 & 0.205 & 0.157 \\
& 0.8 & 0.608 & 0.096 & 24.63 & 2.11 & 0.541 & 0.785 \\
\hline
\end{tabular}

CE.M : composite eye movement, SCEP : slow cumulative eye position.

a)
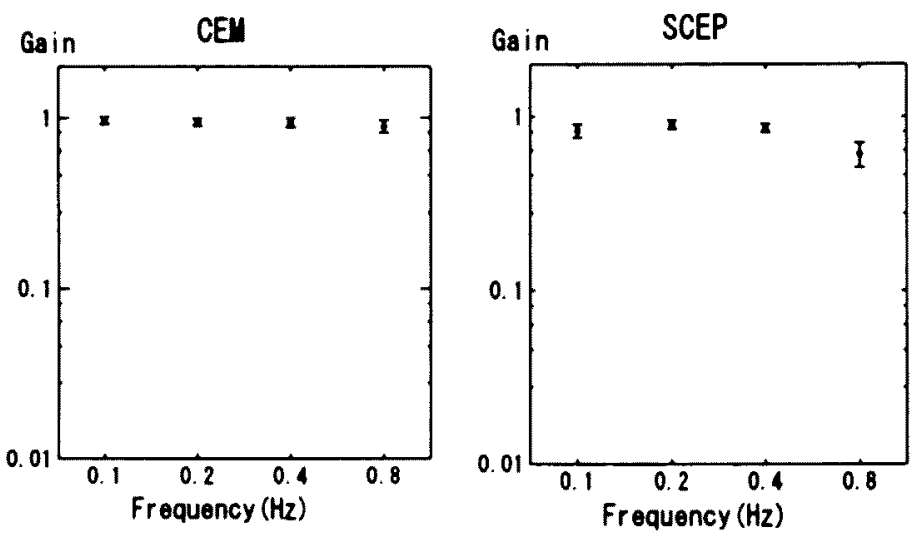

b)
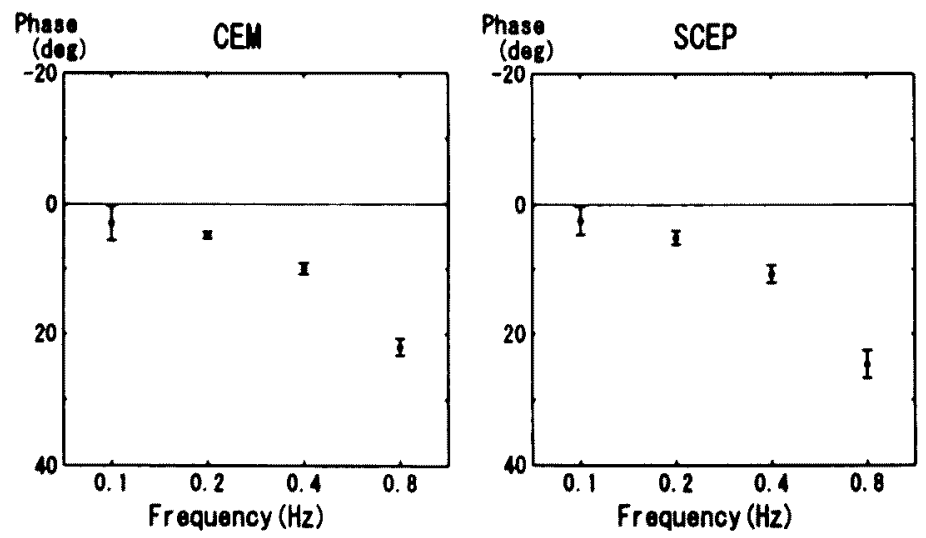

图 4 正常者群の周波数分析結果

a) 仕 gain, b ) は phase の結果を示す. CEM : com. posite eye movement, SCEP : slow cumulative eye position. 

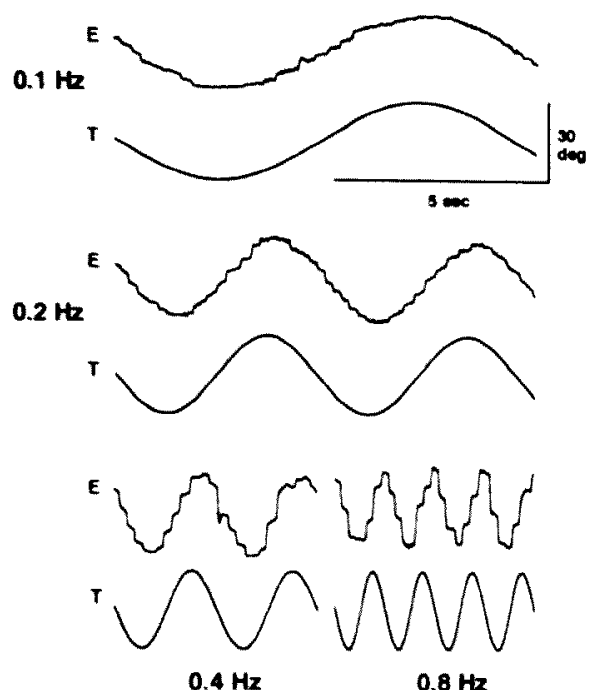

a)
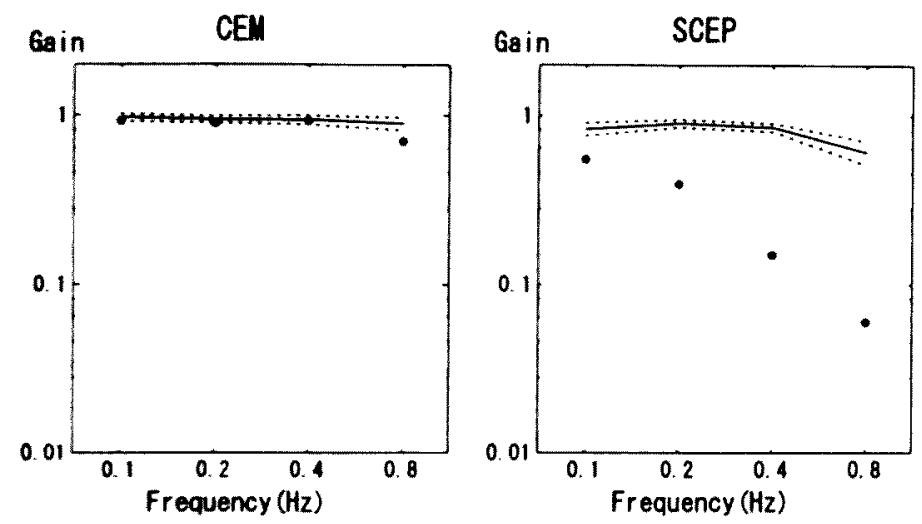

b)

图 5 pursuit gain の低下例（オリーブ楀小脳 卷樎症 (OPCA) の1例)

a)：EOG 波形, b)：分析結果，実線は

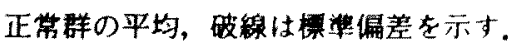

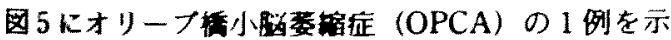

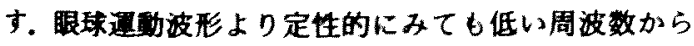
saccade の混入が䛱められいわゆる saccadic pursuit となっている，定目解析ではらに SPEMの gain の 低下は明らかて，入力波の周波数の増大に伴いSCEP の gainが著明に低下しているのがわかる。しかし CEMの gainの低下は訊められず， saccadeによる補 正が活は正確に行かれ，眼球連助全体としてはかなり よく追従できていることがわかる。

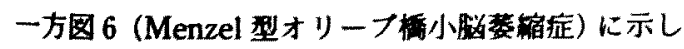

た例では，SPEMの gainの低下のみならずCEMの gainの低下がありこの例では saccadeによる補正も 適切に行われていないのがわかる.図60例は hypometric saccade といえるが，一部の症例ではこ のように saccade の異常をCEM の gain の異常とし て捕らえることができる。

2) phase $の$ 異常例

因 7 に先天性眼层の1例を示す。この例てはSCEP

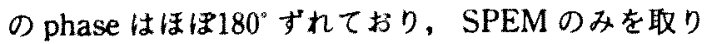
出すと視標の動きと眼球の野きが反対方向という大変 


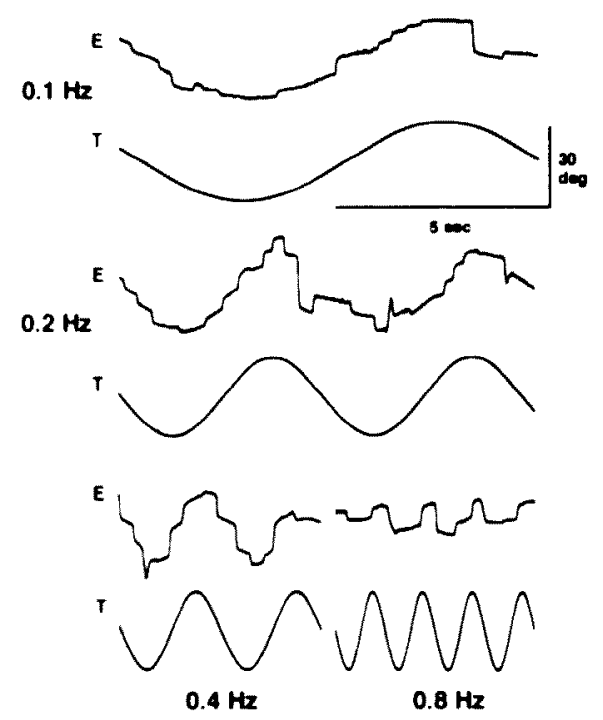

a)
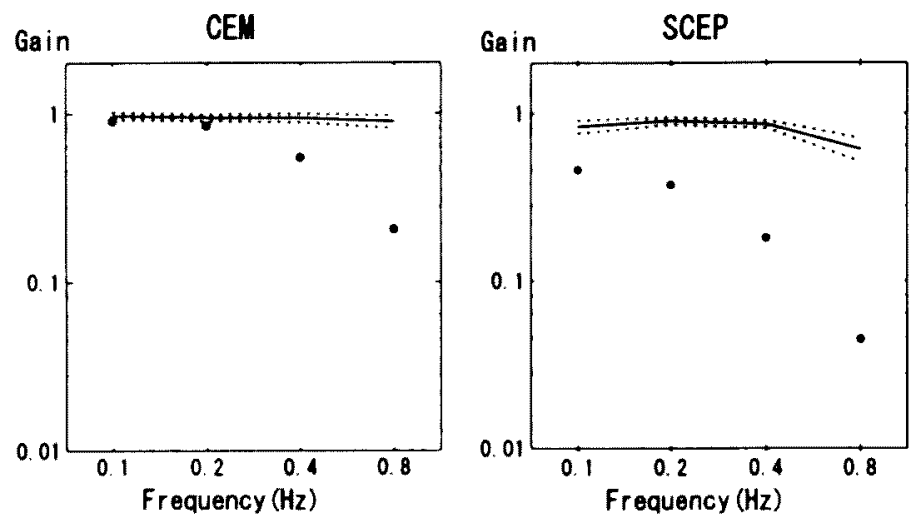

b)

因 6 CEM gain の低下例(Menzel 型オリーフ

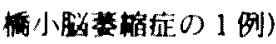

a ):EOG 波形，b）：分析結果，実線は

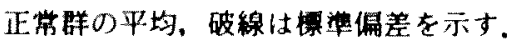

興味源い結果となっだ。

3) トレンドの異常例

因 8 にSPEMに左右差のある症例を示した。この 例のトレンドは $6.81 \%$ sec て正常例に比して大きな值 となっている。

\section{考寀}

1.今回の定悬粍価法の意味付けと従来の方法との 比䑤

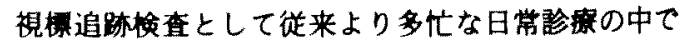
広く简便に用いられているのは，瞒者の指先あるいは ペン先を追視させる方法である。EOGが普及してか らは，模査結果の判定は EOG 記録上の波形のパター ンで定性的に期価され，中枢神経陪害で様々な障害パ ターンが貶録されることが報告されてきだ7)(8)(9).し かし上記のような定性的分析ては, 験者の臨床経験て その判定が左右されるのみならず, 热練した倹者にお いても各データごとの障奢の程度や差異を表現するこ 
$T$

$E$

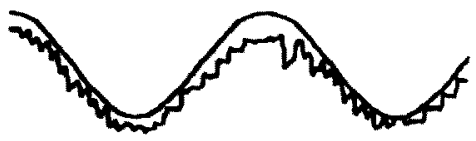

SCEP

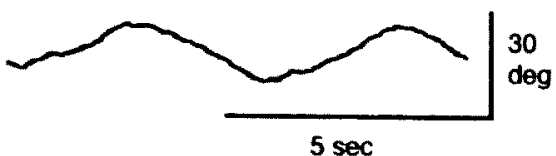

园7 先天性眼振の 1 的

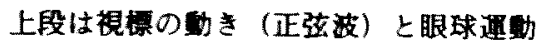
の原波形示す。下段は再消淛された眼

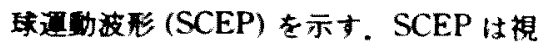
標の娌きとほは逆相になっている。

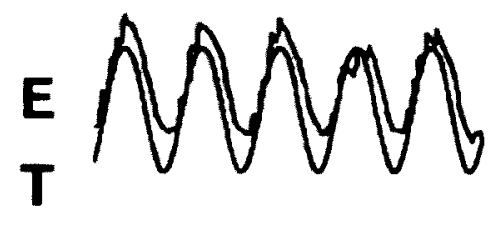

\section{SCEP}

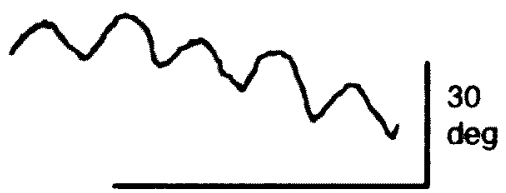

$5 \mathrm{sec}$

因9トレンドの異莹国

SPEMに左右差のある佂例で上段は視

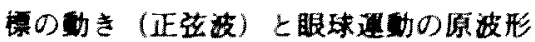

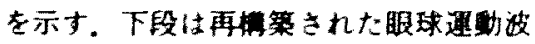
形 (SCEP) を示す (トレント ;6.81\% を除去してある）

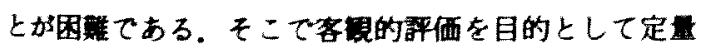
殿析が誈みられるようになった。

用手解析から，コンビューターによる自趿解析まて

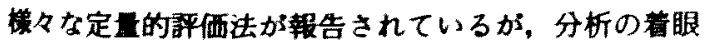
点, 方法について次の上うに大分類できる。

1）一定速度の䘽棈（主に三角波）を用いて速度

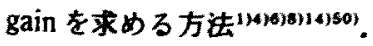

2）視㯲の娌き(入力波)として正弦波を用いて周

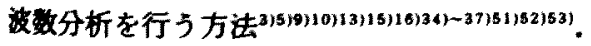

3）追跡眼球運县中に混入している saccadeの頻
度，数，振輻などで評価する方法2(111)541561561.

さらに2)は、視㩯追跡眼球運動を SPEM 成分と saccade成分に分離せずに解析を行っている報 告 ${ }^{33(65) 91101151511521}$ と、分雖した後に SPEM 成分につい て解析を行っている報告(2)131(5)16334)-37153)がある。 我々の分析方法は，後者に属する。

方法論の上で最も重要な点は，SPEM 成分と saccade 成分に分けているかどうかという点である.前述 のようにこの両者は制御システムが全く異なるもので あることから、本来別々に都価されるべでる，両 者を区別せずに眼球塄野全体について分析を行うと， その桔果はSPEMの释洒てはなく, SPEM と sac. cadeの峏者の組み台わさった追従眼球建㽖全体 (overall tracking) を畔価していることになる。これ は我々の方法ては CEM の分析に相当し, SPEM の評 価ではないことに留意すべきでる。

上記に分類したほかにも，パワースペクトルを用い て入力波に一致する周波数のパワー值 (signal) とそれ より高周波数带域のパワー值(noise)を算出し, signal -to-noise ratio の自然対数をとり定量化する方法 ${ }^{57}$, 視標の動きと眼球運動波形の重如合わせを行い，その 不一致の程度を root-mean-square deviation として 定量化する方法 ${ }^{58)}$ なども報告されている．前者は saccade の混入の程度と眼球運動計測時に発生するノイ スを粉台的に評価するものであり，後者は眼球連動計 到時に発生するドリフトが問題になるなど, Ziegler $ら^{\text {(9) }}$ が指摘するように，これらもSPEM の正確な定 化とはいえず，やはり overall tracking の評価にす きないといえる。

3)の方法については，SPEM て視橴を捕らえていく ことがてきなくなると㭪正のための saccade（catchup saccade, back-up saccade) が起こることから, saccade の頻度，数，振滆の絰和などを分析し，間接的 にSPEM を郭価しょうとするものがある。しかし， square-wave jerks ど衛動的な眼球運動が混入して いてもSPEMの gainの低下がみられない場合もあ り、これらは必ずしも SPEM を評価しているとは言 齐ない.

以上より我々の方法のように， saccade 成分を分 離・除去した後 SPEM 成分について分析を行う方法か 最も台理的てあると考える。視標の動さとして三角波 あるいは正弦波のどちらを用いるべきか,コンピュー ターて saccadeを榙出・分離する方法など自野解析に よる定量化の問題点については後述する. 
2. 定量化における諸問題

1）入力波（視標の動き）について

(1) 娭查に用いる波形

視摽の娌き（入力波）として速度が一定の波（三角 波）を用いるか正弦波を用いるかについては，それそ れ一艮一短がある. SPEM 系は速度制卸系 (velocity servo)てあると考えられているのて，速度が一定の波

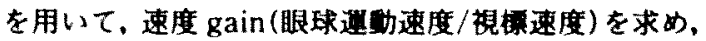
各陚行ごとに梘抟速度を变えて,gainの变化やSPEM の速度限界を知るのはよい方法てある。この㳦合の眼

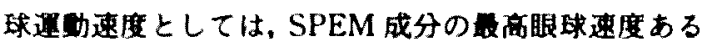
いは正面を通り週ぎるとの眼球速度を用い，数回の 藏行をコンビューターで平均化するのが一般的てあ ろ. Balohら”は，速度上ストクラムを作り各眐行 中最も時間を所要している速度 (mode eye velocity) が， saccade 混入の影算を受けずバラッキが少なく有 用だと報告している。しかし，三角波は変曲点て加速 度が急增大し, smooth pursuit が中断する。 Lisberger ${ }^{601}$ らによれば視標速度のみならず加速度も SPEMに影要を与えるのて，三角波の振幅が小さい場 合や視標速度加速くなると，一方向に速度一定て野く 時間が短くなり, 変曲点ての加速度が速度 gainに影 需すると考充られる。

一方, 正弦波ては速度㧍よび加速度が運䌇的かつ規 則的に変化する。この場合の速度 gainをすへてての点 について求めるのは用手的には困歏て，通常（最高眼

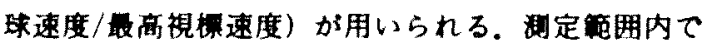
SPEM のシステムが線形であれば, saccade 除去啳に

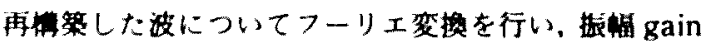
およひ phase を求め周波数分析する我々の用いた方 法が有用てある，また振蜔を変えることにより，同一 周波数ても視係の最两速度や最高加速度を変化させる ことがてきる。

以上のよ5な規則的ではあるが性算の連う2 栢類の 波を視栖として用いた場合，SPEMの速度限界も異な

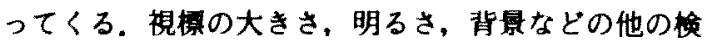
㚗条件にもよるが, 影近ては, 正常者は速度が一定の

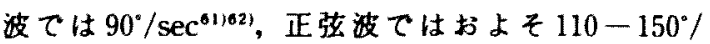
$\sec ^{(0)}$ まて追従でるるという㫰告がある。

(2) 用いる振愊

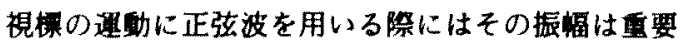
な因子てある。先ほど述べたように同一周波数の視標 刺放を用いても，その振幅が变われば視標の運娌速度 および加速度は異なるのて分析結果も変わる。したが
って梘刺滶に正弦波を使用するときは，振幅の大きさ についての模討が必要てある，この際，用いる眼球運 娌の郡録方法の程類，たとえばEOG，光学式などによ っても使用し得る振幅が規定される。

また，本来周波数応答法による分析は解析しようと する系が線形の部分にのみ適用されるべきて，この場 合 SPEM 系の速度限界や加速度限界に達しない簀囲 で湖定が行かれる必要がある，今回視標の最高速度お

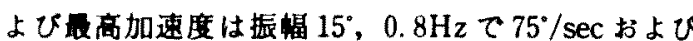
$379^{\circ} / \mathrm{sec}^{2}$ てあり, Lisberger ら ${ }^{(0)}$ の報告による正弦波 における速度限界っょび加速度限界のほほ籍囲内にあ ろ.しかし SPEM 系に陪害のある例ては，これらの限 界に趡している可能性がある．今後，掁幅を全体に小 さくする、あるいは周波数を 2 倍にしたら振幅を $1 / 2 k$ し各周波数間の速度を一定にするなどの検即が必要て あるが,ノイスの湜入の多いEOGでは振幅を小さく 設定すると signal to noise ratio が悪化し分析が困難 となるだめ，自ずと限界がある。

(3) 1 回の試行時間

SPEM は被铪者の集中力に大きく影留され $3^{551581631}$ のて，挨査中は筧醒状態を保つように注意す る必要がある．疲労も検查結果に影誉するので 1 回の 試行時間はでるる限り短い方がよい。しかし試行時間 を短くすると鲜析するデー夕量が少なくなり結果の信 頼性が低下寸るのて，その分試行回数を增やし，各試 行ごとに十分な休蒩をとるのが望ましい．当初我々は 60秒の施行時間でその内の40秒間を分析していたが,

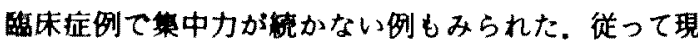
在は、1 回の武行時間を30秒としその内の約20秒間を 解析している。

2）眼球通期計測のハードウエア

眼球塄娌の記録装圈として現在用いられているの は,

(1) EOG

(2) サーチコイル法(4)68)

(3) 光学的方法 ${ }^{(8) 67)}$

などてある。

使用する記録法の穆類と解析のためのアルコリスム には密接な関運がある。すなわち，解析アルゴリスム は記録波形に含まれる/イス成分の性嘪や旦に大きく 依存している，さらに旦子化デー夕により記録される ものては、サンプリング周波数によりアルゴリスムが 変わってくる.

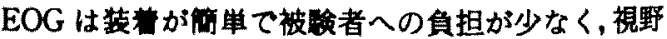


の站げがなく，閉眼や暗所開眼の状照や眼鏡装用者て も記録でるるどの艮所があり、また洒格も安いこと

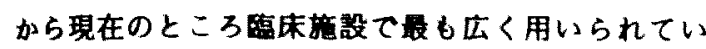

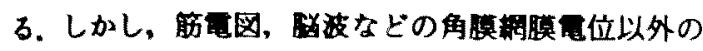
生体電気現象が湦入することゃ DC 衭録時の基線のド

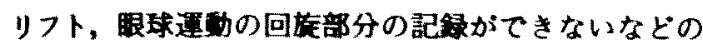
欠点がある. EOG 以外の方法では，サーチコイルは特

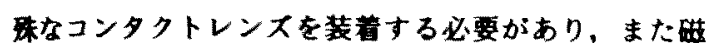
最コイルの中に入らなくてはならないなど頓わしさ がある. 光学的方法は多くの坦合、特なフレームの

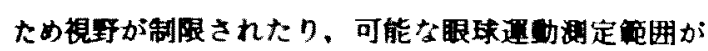
张いことが多い。これらの方法は EOGに比して， イスが少なく、㩆近研究の堨て用いられるようになっ てきたが、いまだ監床的に厸く使用されるには至って いない. 現时点ては, EOGて記録した眼球通㽖に对し

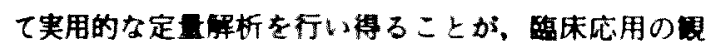
点より必要とされる. /イスの多いEOG 解析可能 なアルコリスムであんば、よりノイスやドリフトの少 ないサーチコイルや光学的方法を用いた記䟿の解析人 の逼はさらに答易でると考えられる。

3) フィルタリンダよびサンナリンタ

EOGを用いて闰したテータでは，50あろいは

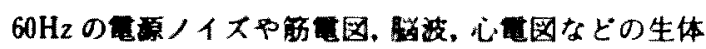

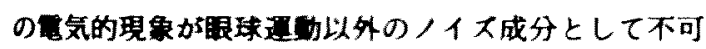

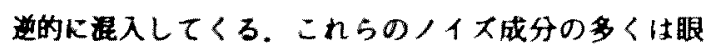
球基功の基本成分と比教して高い周波数成分ておるた め、禹周菠成分を除去するだのフィルターリンダが 不可久てある. 今回は20Hzのフナロダ low-pass フ イルターを用いたが、分析すべきSPEM の周波数成 分は $2 \mathrm{~Hz}$ 以内であるこから SPEM 成分の分析には

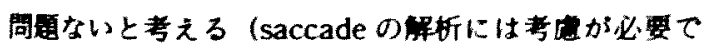
ある).また、データテシタル化した後に，もう一度 平㳻化のためのフィルターをかけている。これは速度 P加速度の計算で分分重るると高周波ノイスが盗調 されてくるため，前もってテータをスムーシングして いるのだが、この場合フィルターをかけすぎると sac. cadeの立ち上がりが鈍くなり， saccadeの模出が困鞋 になってくろ. デジタルフィルターについては分析ア ルコリスムの項て再度述べる。

データのサンプリンクでは，量子化については $12 b i t の \mathrm{~A}-\mathrm{D}$ 㚆换器を用いており，分解能はおよそ $0.01^{\circ} て$, 今回检出しようとしている saccade や/イ スょりも十分小さい、崔散化については，㑭号に含ま れている高周波成分に対してサンブリンク周波数が低
すきると，低い周波数成分に高周波成分が混入してし まうエイリアシンク (aliasing) と呼ばれる問題が生じ る.これを回避するためには，信号成分に比して十分 に高いサンプリング周波数を選ふことと，必要以上に 高い周波数成分を離散化の前に予的取り除いておく必 要がある.SPEM の解析にはサンプリング周波数とし て $60 \mathrm{~Hz} \sim 200 \mathrm{~Hz}$ が多く用いられている. 今回のサン プリング周波数は $200 \mathrm{~Hz}$ (サンプリング周期 $5 \mathrm{~ms}$ ) て。 SPEM の䉽析には問通ないと考えるが, saccade の正 確な解析にはさらにサンプリンタ周期が短い必要があ 3 .

4）分析アルゴリスム

(1) saccade 娭出およU゙除去のためのアルコリスム

コンビューターを用いた眼球運䖝解析の中ても，眼

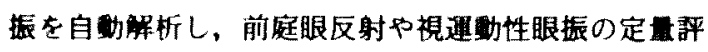
価をしようとする試みは1970年代より数多く行われて きだ(2)88)-75).これらも眼振の急速相 (saccade)を模出 し、急速相と楥徐相を分離し解析を行っている点が本 法と同じであるが、眼振では急速相と緅徐相の向きが 反对でるのに対して，視標追跡眼球運動ては多くの 場合 saccade とSPEM が同方向であるので, saccade の挨出はより難しい。ささらにノイスの多いEOG 記録 の解析には困歏が伴う. saccade検出における問題点 は，峦速の SPEM と比較的速度の迫い saccade $の 区$ 別と，ノイスと saccade の分崔の二点にしほららる。

前者の改喑のためには次の二つの方法がある。一つ

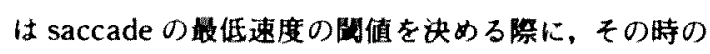

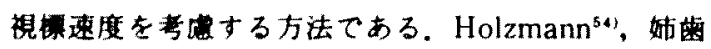

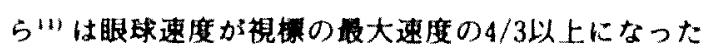
場合を saccadeとして娭出しており，Bahill ら501 は彼 らの使用している視摆速度が常に40\% ことから間值を $50^{\prime \prime} / \mathrm{sec} に$ 設定しているが、これらは

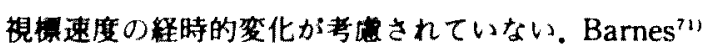
は，VOR の眼球遇動波形から急速相と楥徐相を分離 する際に，刺波のビークとその時の最大縟徐相速度 を先に同定しておき，刺做波の波形およびノイスの状

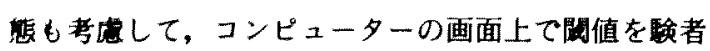
が設定てき、悢徐相速度の変化に伴い閏值も自動的に 変化させるシステムを考案しているが, 視標追跡眼球 遇動でもこの方法を応用することができる。また

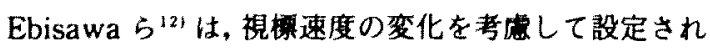
た速度阳傎を用いて saccade を娭出・除去した後, 得 られたSPEMの速度波形をフーリエ変换しgain phase t計算し、実際のSPEM の速度波形に gain 
低下と位相のスレについて偣正を加え仮想の SPEM の速度波形なるものを夏き、これよりもう一度速度䦥 值を決定し直す方法（彼らはこれをフィードパック法 と呼んている）を報告している．高速の pursuit と saccade を区別するためのもう一つの方法は，二次效

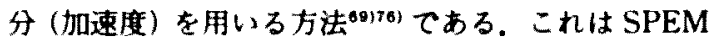
と saccade の行点て速度が大きく傩化する，すなか ち加速度が急に大きくなることを利用している，松阙 ら ${ }^{46)}$ はこの考之方を進めて，さらに三次敏分（加加速 度）を用いると耐者が容易に践別でると郝告してい

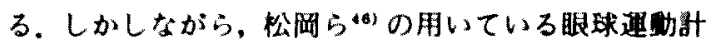
湖装目は光学式のものてあり，EOGのようにノイス 成分の多い方法ては必ずしも有奻と国之ない。

後者のノイスとの分㽫についてはフィルターリンタ が重要な意味を持つ，一般的な平均化デジタル・フィ ルタてはノイスを完全に除去しようとしてフィルター をかけすぎると、 saccadeの立ち上がりが钝り sac cade の最大速度が低下し"n，かえって SPEM との誠

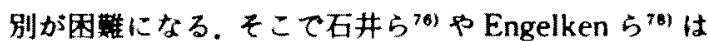
特殊なフィルター考案している. 石井ら ${ }^{76)}$ のフル 夕ーは EOG の单眼誘䓕の時系列上り，左眼上右眼て 逆位相の成分（眼球運動は二つの誘迋間で这位相にな るが，他のノイス成分は無相関である）のみを通すも ので大要興味㴗い。

我々は, saccade の正確な検出のために、平均化デジ タル・フィルターを通した後、速度波形て折り返して いるビークの部分を模出し，それが saccade として罗 当であるかいくつかの条件を数定した。モの中には速

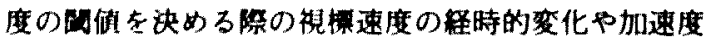

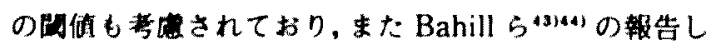
ている一般的な saccade $の$ 特致とるかという 点も条件項目に取り入れている.しかし saccade 娭出 のための条件は眼球通野波形に合まれるノイスの性算 や量、およびそれを除去するために用いたフィルター の特性，鹤化する祭の周波数により大きく左右され ろ. 従って，我々の規定した saccade 模出のための条 件は，生理学的な saccade の特徽に基ずいたにのては あるが、そこて用いられる条件の数值は測定系や噰散 化およびフィルターに依存するものであり，数值决定

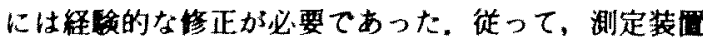
の変更やサンブリンダ周波数の変更，フィルターの変 更などに伴って saccade 模出のための条件は変更さ れる必要がある。

以上のような我々の方法あるいは他の研究者の方法
によっても，自動処理てきない数\%の saccade が残存 する。 また saccadeを完全に取り除こうとして saccade 模出の条件を緅やかにすると、ノイス成分を哭っ て saccade として就践してしまう卒が高くなり，その 結果として解析結果がゆがめられる危険がある。そこ で我々は現時点ては、コンピューターの画面上て雅者 が saccade 除去の結果の点娭ができ，残存している saccade をカーソルで指定し追加除去できるマニュア ル操作をプログラムに加えている。これによりノイス レベルを劭える saccadeについてはほほほ100\%除去 可能てある.

さらにこれとは別の問題として，疾病によって saccade の速度が幄い埸合や特殊な異常眼球運動を持つ 上うな例では，現在のところ自動処理は困難てありマ ニュアル指作を介在させることが必要である.

(2) 周波数分析

有限畏のデータをスペクトル解析する際には，スペ クトル推定顛差を娍ずるために適当なスペクトルウィ ンドウを措ける必要がある ${ }^{79}$. しかしウィンドウ処理 によりデータの霆が必ず生じる，そこで我々は，ウィ ンドウ処理の必要性をなくすために，データの最初と 取後の点がつながるように、データ長が使用する周期 のほほ篮数倍になるように設定しこの問題を回避し た. 周波数分析の际のスベクトルの計算法としては， FFT（高速フーリエ変倠）とMEM（最大エントロピ 一法)が有名であか、FFTの方がアルコリスムが容 易て計算速度が速いこと，MEM は俱差が少なくピー ク検出に隊れているが，ピークの定量（この場合は gainの計算)にはFFT が通していることから，視標追 跡眼球遇野の解析にはFFTを採用している報告が多

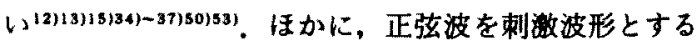
埸合には最少 2 乗法を用いる方法もあるが，我々は将 来刺敏波形として pseudorandom 波を用いる計画が あり、FFT 法を選択した。

(3) 要求されるパラメータ

SPEM と saccade とノイスを正確に分離すること ができたならば，将来的には異なる制御システムを持 つニつの眼球遇娌それそれについてパラメー夕を設定 して定目的評価を行うのが理想でる。前述したよう に， saccade を除去する前の CEM に対する分析は追 従眼球運動全体 (overall tracking)の評価を意味する。 SPEMに対するパラメータとしては，考えられ得る 䝨常形式の項て述へたように，周波数分析によりgain と phase を求めるのが一般的である。 
saccade を語価するパラメータとしては，saccade の速度, 振愊, 出現顆度、出現間雨のバラツキなどが 考えられる.二つの眼球通助を分醮した後に saccade についても定量的評価を行与方法が報告されてい

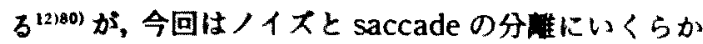
問䕗が残っているため saccade そのものに対する評 面俚行っていない.

\section{ま}

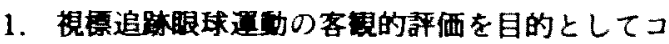
ンピューターを用いた定量解析を郝告しだ。

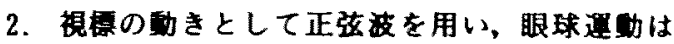

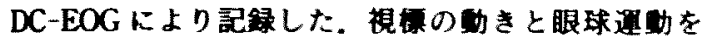

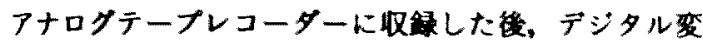
邹しバーソナルコンビューターに取り込みこれを解析 した.

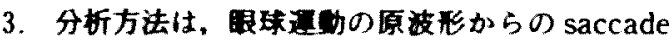

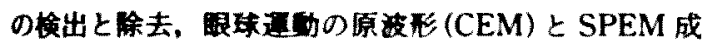
分 (SCEP) の周陂数分析から成り立っている.

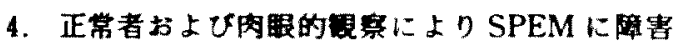

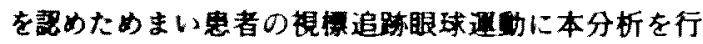
いそその落果を提示し本方法ての极能巽常の捕㰾方 を示した。

5. 今回の周波政店答法によ了定量解析は，従来の 定性的分析とも矛盾なく対底し，ほ㴗正確に定量化て きていると考える。また文社的考祭から他の報告者の 方法と比较しても，SPEM 成分の定評価法として十 分信頼性があると考える。

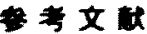

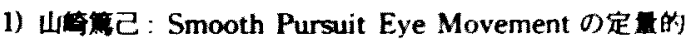
定法. 湢眼 31：1161-1164，1977。

2) Umeda $Y$ : Manual quantitative assessment of eyetracking patterns. Ann Otol Rhino Laryngol 89 Suppl $71: 1-6,1980$.

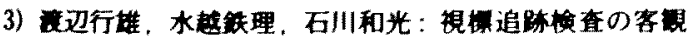
判定化への試み（第 1 暳). Equillibrium Res 33:98101, 1974.

4) Baloh RW, Kumley WE, Sills AW et al: Quantita. tive measurement of smooth pursuit eye move. ments. Ann Otol Rhinol Laryngol : 1976.

5) Wolfe JW, Olson JW, Engelken EJ : Cross-power spectral density analysis of pursuit tracking Evaluation of central and peripheral pathology. Ann Otol 87 : 837-844, 1978.
6) Schalen L: Quantification of tracking eye movements in normal subjects. Acta Otolaryngol Stockh 90: 404-413, 1980.

7) Bittencourt PRM. Smith AT, Lloyd DSL: Determination of smooth pursuit eye movement velocity in humans by computer. Electroenceph clin Neurophysiol 54 : 399-405, 1982.

8) Bergenius J : Computerized analysis of voluntary eye movements. A clinical method for evaluation of smooth pursuit and saccades in oto-neurological diagnosis. Acta Otolaryngol (Stockh) $98(5-6)$ : 490-500, 1984.

9) Ohashi N. Watanabe Y, Kobayashi H et al : Quantitative measurement of smooth pursuit using a continuously changing sinusoidal wave in normal subjects. ORL J Otorhinolaryngol Relat Spec 47 (1): 49-56, 1985.

10) Miles R, McFate $R$, Olin $B$, et al : An eye tracking system for diagnosing CNS disorders. Biomed Sci Instrum $21: 73-76,1985$.

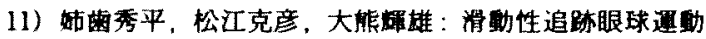
害の定的自解析法。臨休䏚波 27(5)：275-282， 1985.

12) Ebisawa $Y$, Minamitani $H$, Mori $Y$, et al: New methods for removing saccades in analysis of smooth pursuit eye movement. Biol Cybern 60 : 111-119, 1988.

13) Larsby B : Pursuit eye movements. Methodological aspects. Acta Otolaryngol Suppl (Stockh) 455: $24-27,1988$

14) Allum JH, Honegger F, Ura M. et al: Automatic electronystagmus analysis and documentation: recent advances in the study of vestibular, optokinetic and pursuit tracking function. ORL J Otorhinolaryngol Relat Spec 51 : 14-32, 1989.

15) Engelken E, Stevens K, Enderle J : Computer analy. sis of smooth pursuit eye movements. Biomed Sci Instrum 25: 127-133, 1989.

16) Sauter D, Martin BJ, Di Renzo N, et al : Analysis of eye tracking movements using innovations generated by a Kalman filter. Med Biol Eng Comput 29 : 63-69, 1991.

17) Newsome WT, Wurtz RH, Dursteler MR, et al: Deficits in visual motion processing following ibotenic acid lesions of the middle temporal visual area of the macaque monkey. J Neurosci $5: 825$ $840,1985$. 
18) Newsome WT, Wurtz RH, Dursteler MR, et al: Punctate chemical lesions of striate cortex in the macaque monkey: Effect on visually guided sac. cades. Exp Brain Res 58 : 392-399, 1985.

19) Optican LM. Robinson DA: Cerebellar-dependent adaptive control of primate saccadic system. J Neurophysiol 44: 1058-1076, 1980.

20) Zee DS, Yamazaki A, Butler PH, et al: Effects of ablation of flocculus and paraflocculus of eye movements in primate. J Neurophysiol 46: 878-899, 1981.

21) Rashbass $C:$ The relationship between saccadic and smooth tracking eye movements. J Physiol 159 : 326-338, 1961

22) Robinson DA: The mechanics of human smooth pursuit eye movement. J Physiol Lond 180 : 569 591. 1965.

23) Westheimer G. Mckee SP: Visual acuity in the presence of retinal-image motion. J Opt Soc Am $65: 847-850,1975$

24) Murphy BJ: Pattern thresholds for moving and stationary gratings during smooth eye movement. Vision Res 18: 521-530, 1978.

25) von Noorden GK, Mackensen G: Pursuit movements of normal and amblyopic eyes. An electroophthalmographic study 1. Physiology of pursuit movements. Am J Ophthalmol : 325-336, 1962.

26) Deckert GH : Pursuit eye movements in the absence of a moving visual stimulus. Science 143: 1192. 1193,1964

27) Heywood S, Churcher J : Eye movements and the afterimage. 1. Tracking the afterimage. Vision Res $11: 1163-1168,1971$.

28) Gauthier GM, Hofferer JM: Eye movements in response to real and apparent motions of acoustic targets. Percept Mot Skills 42: 963-971, 1976.

29) Steinbach MJ : Pursuing the perceptual rather than the retinal stimulus. Vision Res 16:1371-1376, 1976.

30) Ward R, Morgan MJ : Perceptual effect of pursuit eye movements in the abscence of a target. Nature 274: 158-159, 1978.

31) Morgan MJ, Tumbull DF: Smooth eye tracking and the perception of motion in the absence of real movement. Vision Res 18: 1053-1059, 1978.

32) Collewijn H, Curio G, Grusser OJ : Spatially selective visual attention and generation of eye pursuit movements. Experiments with sigma-movement. Hum Neurobiol 1: 129-139, 1982.

33) van der Steen J, Tamminga EP, Collewijn H: A comparison of oculomotor pursuit of a target in circular real, beta or sigma motion. Vision Res 23 : 1655-1661, 1983.

34) Collewijn $\mathrm{H}$, Tamminga EP : Human smooth and saccadic eye movements during voluntary pursuit of different target motions on different backgrounds. J Physiol Lond 351 : 217-250, 1984.

35) Yasui S, Young LR: On the predictive control of foveal eye tracking and slow phases of optokinetic and vestibular nystagmus. J Physiol Lond $347: 17$ $-33,1984$.

36) Barnes GR, Donnelly SF, Eason RD: Predictive velocity estimation in the pursuit reflex response to pseudo-random and step displacement stimuli in man. J Physiol Lond 389: 111-136, 1987.

37) Barnes GR, Ruddock CJ: Factors affecting the predictability of pseudorandom motion stimuli in the pursuit reflex of man. J Physiol Lond 408: 137 $-165,1989$.

38) Yasui S, Young LR: Perceived visual motion as effective stimulus to pursuit eye movement system. Science $190: 906^{-908, ~} 1975$.

39) Robinson DA: The systems approach to the oculomotor system. Vision Res 26 (1): 91-99, 1986

40) Lisberger SG, Morris EJ, Tychsen L: Visual motion processing and sensory-motor integration for smooth pursuit eye movements. Annu Rev Neur osci $10: 97-129,1987$.

41) Westheimer $G$ : Eye movement responses to a horizontally moving visual stimulus. AMA Arch Ophthalmol 52 : 932-941, 1954.

42) Arzi M, Magnin M: A fuzzy set theoretical approach to automatic analysis of nystagmic eye movements. IEEE Trans Biomed Eng $36(9)$ : 954963, 1989.

43) Bahill AT, Clark MR, Stark L: The main sequence, a tool for studying human eye movements. Mathematical Bioscience 24 : 191-204, 1975.

44) Bahill AT, Brockenbrough A, Troost BT : Variabil ity and development of a normative data base for saccadic eye movements. Invest Ophthalmol Vis Sci 1981 .

45) Inchingolo $P$, Spanio $M$ : On the identification and analysis of saccadic eye movements - $\mathrm{A}$ quantita. 
tive study of the processing procedures. IEEE Trans Biomed Eng BME-32: 683-695, 1985.

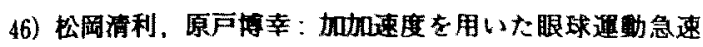
相の凂出、人間工学 $19: 147-153 、 1983$.

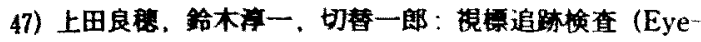
Tracking Test). 耳告床 $60: 918-925,1967$.

48) Corvera J. Torres CG. Lopez RG: The neurotological significance of alterations of pursuit eye movements and the pendular eye tracking test. Ann Otol Rhinol Laryngol 82: 855-67, 1973.

49) Benitez JT: Eye-tracking and optokinetic tests : diagnostic significance in peripheral and central vestibular disorders. Laryngoscope 80: 834-848, 1970.

50) Bahill AT, landolo MJ. Troost BT : Smooth pursuit eye movements in response to unpredictable target waveforms. Vision Res 20: 923-931, 1980.

51) Dallos PJ. Jones RW : Learning behavior of the eye fixation control system. IEEE Trans Automatic Control AC-8:218-227, 1963.

52) Michael JA. Jones GM : Dependence of visual track ing capability upon stimulus predictability. Vision Res 6: 707-716. 1966

53) Matsuoka K. Ueda $\mathrm{Y}$ : Frequency characteristics of the smooth pursuit component in tracking eye movements. Ergonomics 29: 197-214, 1986.

54) Holzmann PS. Proctor LR. Hughes DW : Eye-track. ing patterns in schizophrenia. Science 181: 179181, 1973.

55) Shagass C, Roemer RA. Amadeo M : Eye-tracking performance and engagement of attention. Arch Gen Psychiatry 33 : 121-125, 1976.

56) Hutton JT, Nagel JA, Loewenson RB : Eye tracking dysfunction in Alzheimer type dementia. Neurol. ogy $34: 99-102,1984$.

57) Lindsey DT, Holzman PS, Haberman S: Smooth pursuit eye movements: A comparison of two measurement techniques for studying schizophre nia. J Abnorm Psychol 87 : 491-496, 1978.

58) lacono WG, Lykken DT: Electro-oculographic recording and scoring of smooth pursuit and sac. cadic eye tracking : a parametric study using monozygotic twins. Psychophysiology 16: 94-107, 1979.

59) Ziegler AS, Abel LA, Dell'Osso LF : To say bad isn $t$ good enough - nonspecificity of the LN(S/N) ratio for smooth pursuit analysis. Invest Ophthal. mol Vis Sci 27 (suppl) : 58, 1986.

60) Lisberger SG, Evinger $C$, Johanson $G W$, et al : Relationship between eye acceleration and retinal image velocity during foveal smooth pursuit in man and monkey. J Neurophysiol $46: 229-249,1981$.

61) Barmack NH : Dynamic visual acuity as an index of eye movement control. Vision Res 10: 13771391, 1970.

62) Meyer C. Lasker A, Robinson DA: The upper limit of human smooth pursuit velocity. Vision Res 25 (4) : 561-563, 1985.

63) Wyatt HJ, Pola J: Smooth eye movements with step-ramp stimuli: the influence of attention and stimulus extent. Vision Res 27: 1565-1580, 1987.

64) Robinson DA : A method of measuring eye move. ment using a scleral search coil in a magnetic field IEEE Trans Biomed Eng BME-10:137-144, 1963.

65) Collewijn $H$, van der Mark F, lanses TC: Precise recording of human eye movements. Vision Res 15: $447-450,1975$

66) Bahill AT, Clark MR, Stark L: Dynamic overshoot in saccadic eye movements is caused by neurological control signed reversals. Exp Neurol 48: 107-122, 1975.

67) Scherer H, Teiwes W, Clarke AH : Measuring three dimensions of eye movements in dynamic situations by means of videooculography. Acta Otolaryngol $111: 182-187,1991$.

68) Allum JHJ, Tole JR, Weiss A: MITNYS-II-A digital program for on-line analysis of nystagmus. IEEE Trans Biomed Eng BME-22 : 196-202, 1975.

69) Michaels DL. Tole JR: A microprocessor-based instrument for nystagmus analysis. Proceedings of IEEE $65: 730-735,1977$.

70) Wall III C, Black FO: Algorithms for the clinical analysis of nystagmus eye movements. IEEE Trans Biomed Eng BME 28: 638-646, 1981

71) Bames GR: A procedure for the analysis of nystag mus and other eye movements. Aviat Space Environ Med $53: 676-682,1982$

72）野上兼一郎，上村卓也，岩元正広: 眼振急速相嗏出の たかの1アルコリスム，耳臨床 77:2309-2315， 1984 .

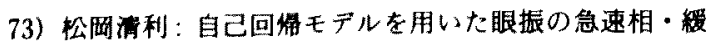
徐相の分部，九州工莱大学研究報告（工学） $54: 45-$ $50,1987$.

74) Juhola $M$ : Detection of nystagmus eye movements 
using a recursive digital filter. IEEE Trans Biomed Eng 35 : 389-395, 1988.

75) Engelken EJ, Stevens $\mathrm{KW}: \mathrm{A}$ new approach to the analysis of nystagmus: An application for order statistic filters. Aviat Space Environ Med 61: 859 $-864,1989$.

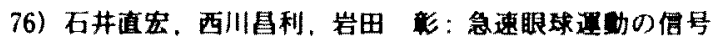

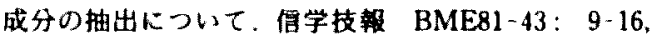
1981.

77) Juhola $M$ : The effect of digital lowpass filters in the maximum velocity of saccadic eye movements. Comput Biol Med 16:361-370, 1986.

78) Engelken E, Stevens K. Enderle J : Development of a non-linear smoothing filter for the processing of eye-movernent signals. Biomed Sci Instrum $26: 5$
$-10,1990$.

79）日野䑶：スベクトル解析，朝合至店，東京，154175面, 1979 .

80) Abel LA, Ziegler AS: Smooth pursuit eye move ments in schizophrenics - what constitutes quanti tative assessment? Biol Psychiatry $24: 747-761$, 1988.

本的文の一部は第58回東海地方部会連合会および第48回 日本平行神維科学会にて発表した。

(1995年1月13日受程 1995年3月2日受理 急武)

别剧期求先

名古屋市立大学医学部耳咽喉科学数室 羽柴基之 


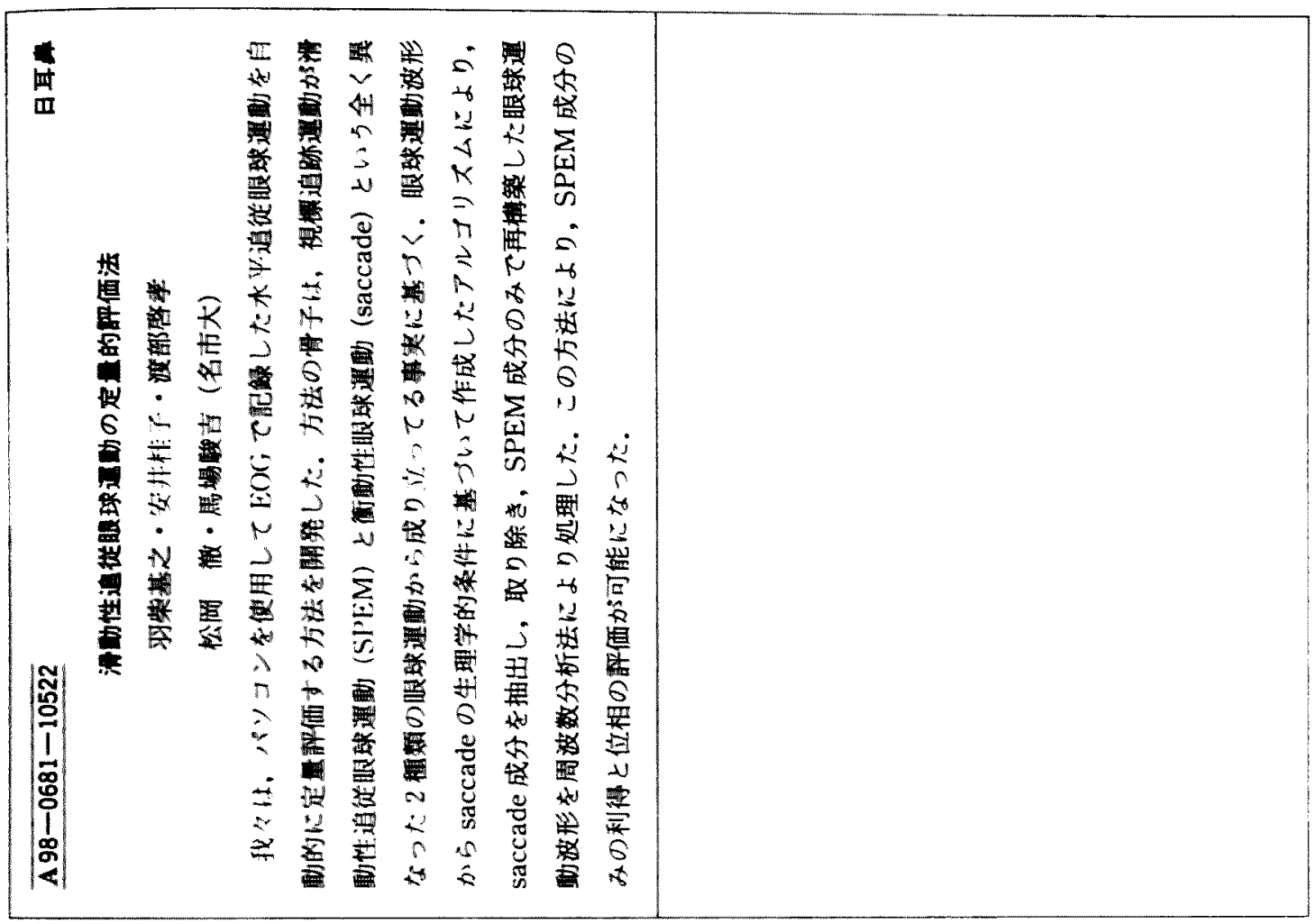

